\title{
SUATU MODEL PENDIDIKAN DENGAN SISTEM BELAJAR MANDIRI
}

Oleh: Uwes Anis Chaeruman *

\section{Abstract}

This case study research was focused to find out what, why and how (1) PGMKSBM was implemented; and (2) the diffusion of PGMKSBM was taken. Data collection techniques used were (1) questionnaires; (2) in-depth interviews; and (3) documents and archives analysis. Scope of the study was limited only to the implementation of PGMKSBM in Banten Province.

Research findings show that PGMKSBM is an in-service training program aimed to enhance the teacher'qualification ( $D-2$ or $D$ 3) for teachers who are still active teaching but do not has qualification as required, yet. PGMKSBM has some unique characteristics, i.e. (1) it's in-service training program, not preservice training program; (2) using independent learning system that integrated with the daily teaching practices; (3) applying collaborative action research approach to synergize between theory and daily teaching practices; (4) using authentic assessment technique (portfolio) beside pencil on paper test as learning assessment tools; and (5) use peers and principals as partner and learning resources. Success of PGMKSBM implementation can be showed by some indicators, i.e. (1) quantity of graduated students; (2) improvement of student' mastery of teaching; (3) teacher performance improvement in school; and (4) improvement on student' achievement.

Kata Kunci:,independent learning system, self-directed learning, diffusion and innovation, case study, in-service training, collaborative action research, authentic assessment (portfolio),

*) Uwes Anis Chaeruman, M.Pd adalah staf Bidang Teknologi Informasi pada Pusat Teknologi Informasi dan Komunikasi Pendidikan (Pustekkom) Departemen Pendidikan Nasional. 


\section{A. PENDAHULUAN}

\section{Latar Belakang}

Sampai saat ini, pendidikan nasional masih menghadapi berbagai tantangan. Dua diantaranya adalah uaya peningkatan mutu pendidikan dan perluasan serta pemerataan akses pendidikan. Lemahnya mutu pendidikan, salah satu diantaranya disebabkan oleh rendahnya kualifikasi guru. Masih banyak tenaga guru belum memiliki kulaifikasi yang dipersyaratkan. Sebagai contoh, sampai tahun 1996, tercatat sekitar 600 ribu orang guru yang belum memenuhi kulaifikasi. Permasalahan tersebut ditambah dengan ketidakmampuan LPTK untuk menyelenggarakan program pendidikan dengan cara tatap muka (konvensional). Sementara disisi lain, tuntutan di lapangan (baik guru, pemerintah pusat maupun daerah) untuk memperoleh kualifikasi yang dipersyaratkan semakin meningkat.

Kenyataan ini menuntut adanya terobosan atau inovasi baik dalam rangka peningkatan mutu maupun perluasan serta pemerataan akses pendidikan. Berbagai inovasi telah dan sedang dilakukan untuk mewujdukan hal tersebut. Diantaranya adalah SD PAMONG, SMP Terbuka, SMU Terbuka, Universitas Terbuka dan lain-lain. Salah satu inovasi pendidikan lain yang menarik perhatian peneliti adalah upaya peningkatan kualifikasi guru yang diselenggarakan oleh Pusat Pengembangan Penataran Guru Tertulis (P3GT) Bandung bekerjasama dengan Universitas Negeri Sebelas Maret (UNS). Sejak tahun 1996/ 1997, P3GT dan UNS sedang mengembangkan program pendidikan inovatif untuk meningkatkan kualifikasi guru setara D2 dan D3. Inovasi tersebut dinamakan Pendidikan Guru Model Kualifikasi dengan Sistem Belajar Mandiri atau disingkat PGMKSBM. Untuk pertama kalinya, model pendidikan tersebut dilaksanakan di Jawa Tengah dan Jawa Barat. Sebagai suatu inovasi, PGMSKBM berpotensi untuk terus dikembangkan dengan harapan pada akhirnya dapat disebarkan dan diadopsi sebagai salah satu model dalam upaya meningkatkan kualifikasi guru. 
UNS sebagai pihak pengembang dan penyelenggara menyadari bahwa model pendidikan ini masih memerlukan penyempurnaan dengan cara memperbaiki segala kelemahan dari setiap komponen sistemnya. Dengan demikian, diperlukan suatu upaya ilmiah untuk menggali informasi bagaimana inovasi pendidikan ini didifusikan dan diselenggarakan seraya mengidentifikasi faktor-faktor penyebab keunggulan dan kelemahannya. Pemikiran inilah yang mendasari peneliti untuk melakukan penelitian ini.

\section{Pertanyaan Penelitian}

Mengacu kepada latar belakang penelitian di atas, terdapat beberapa pertanyaan yang penting untuk digali dalam penelitian ini. Beberapa pertanyaan penelitian tersebut adalah sebagai berikut:

a. Apa dan mengapa PGMKSBM dikembangkan?

b. Apa sajakah indikator keberhasilan PGMKSBM?

c. Sebagai suatu inovasi, bagaimana inovasi PGMKSBM di difusikan?

d. Bagaimana PGMKSBM di selenggarakan?

e. Seberapa jauh keberhasilan penyelenggaraan PGMKSBM?

f. Faktor-faktor apa saja yang mendukung dan menghambat keberhasilan PGMKSBM di wilayah Banten?

\section{Batasan Penelitian}

Program Pendidikan Guru Model Kualifikasi dengan Sistem Belajar Mandiri ini ditujukan untuk meningkatkan kualifikasi guru setara D2 dan D3 di Indonesia. Lingkup penelitian ini dibatasi hanya untuk PGMKSBM di wilayah Banten, yang meliputi Kabupaten Serang, Lebak dan Pandeglang.

\section{Tujuan Penelitian}

Sesuai dengan pertanyaan-pertanyaan penelitian yang diajukan, tujuan penelitian ini adalah:

a. Mendeskripsikan secara lengkap apa adanya tentang apa yang dimaksud dengan PGMKSBM dan alasan 
pengembangan PGMKSBM;

b. Menggambarkan indikator keberhasilan tujuan PGMKSBM;

c. Mendeskripsikan secara lengkap apa adanya tentang upaya difusi inovasi PGMKSBM tersebut;

d. Mendeskripsikan secara lengkap apa adanya tentang penyelenggaraan PGMKSBM;

e. Menilai sejauh mana PGMKSBM tersebut berhasil diimplementasikan; dan

f. Menganalisis berbagai faktor yang mendukung dan menghambat penyelenggaraan PGMKSBM.

\section{Kegunaan Penelitian}

Hasil dari penelitian ini diharapkan dapat dijadikan sebagai :

a. bahan masukan dalam upaya penyempurnaan Pendidikan Guru Model Kualifikasi dengan Sistem Belajar Mandiri di masa yang akan datang;

b. bahan acuan bagi penyelenggara model pendidikan yang menerapkan sistem belajar mandiri lain, seperti SMP Terbuka, SMU Terbuka, Universitas Terbuka, Program Pendidikan Akta dengan Sistem Belajar Mandiri, Program Pelatihan/Penataran dengan Sistem Belajar Mandiri, dan lain-lain; dan

c. secara umum dapat menambah khasanah ilmu atau pengetahuan baru tentang penyelenggaraan pendidikan dengan sistem belajar mandiri.

\section{Acuan Teoretis}

\section{Sistem Belajar Mandiri}

a. Konsepsi Belajar Mandiri

Ada beberapa istilah yang mengacu pada pengertian yang sama tentang belajar mandiri. Menurut Candy (2000, hal 1), istilah-istilah tersebut adalah 1) independent learning, 2) self-directed learning dan 3) autonomous learning. Wedemeyer (1973) seperti dikutip oleh Keegan (1990, hal 54), menjelaskan belajar mandiri sebagai pembelajaran yang merubah prilaku, dihasilkan 
dari kegiatan-kegiatan yang dilakukan oleh pebelajar dalam tempat dan waktu berbeda serta lingkungan belajar yang berbeda dengan sekolah. Pebelajar mungkin dibimbing oleh guru tapi tidak tergantung kepada mereka. Pebelajar menerima derajat kebebasan dan tanggung jawab dalam merencanakan dan melakukan kegiatan-kegiatan yang mendorong kearah terjadinya belajar. Dengan demikian, dapat disimpulkan bahwa belajar mandiri lebih berorientasi kepada pebelajar dimana pebelajar mempunyai kebebasan dan tanggung jawab yang besar atas belajarnya sendiri.

Rowntree (1992, h. 61), dengan mengutip penjelasan Lewis dan Spencer (1986) menjelaskan pengertian belajar mandiri dalam konteks pendidikan terbuka. la mengatakan bahwa ciri utama dari pendidikan terbuka adalah adanya komitmen untuk membantu pebelajar memperoleh independensi dan kemandirian. Dimana pebelajar mempunyai kemandirian dalam mengambil atau menentukan keputusan sendiri tentang: 1) tujuan atau hasil belajar yang ingin dicapai; 2) mata ajar, tema, topik, atau issu yang akan dipelajari; 3) sumber-sumber belajar dan metode yang akan digunakan; dan 4) kapan, bagaimana serta dalam hal apa keberhasilan belajarnya akan diuji (dinilai). Dalam pengertian ini, pebelajar diposisikan sebagai subyek, pemegang kendali atau pengambil keputusan atas belajarnya sendiri.

Knowles (1975, h. 18) menggambarkan belajar mandiri sebagai suatu proses dimana individu mengambil inisiatif dengan atau tanpa bantuan orang lain untuk: 1) mendiagnosa kebutuhan belajarnya sendiri; 2) merumuskan/menentukan tujuan belajarnya sendiri; 3) mengidentifikasi sumber-sumber belajar; 4) memilih 
dan melaksanakan strategi belajarnya; dan 4) mengevaluasi hasil belajarnya sendiri. Dari pernyataan diatas dapat disimpulkan bahwa belajar mandiri menekankan pada peran individu sebagai penanggung jawab dan pemegang kendali dalam memenuhi dan mencapai keberhasilan belajar.

Pernyataan-pernyataan para ahli di atas menjelaskan beberapa unsur dari konsep belajar mandiri. Pertama, kebutuhan belajar adalah tanggung jawab pebelajar itu sendiri. Kedua, pebelajar memegang kendali dalam pengambilan keputusan untuk mencapai kebutuhan belajarnya tersebut. Terakhir, dalam upaya mencapai kebutuhan belajarnya tersebut, mereka secara individu atau kelompok dapat meminta bantuan kepada orangorang lain yang relevan, seperti guru/tutor, teman dan lain-lain.

b. Konsep Dasar Program Pendidikan dengan Sistem Belajar Mandiri

Seperti dijelaskan di atas, konsep dasar sistem belajar mandiri adalah pengaturan program belajar yang diorganisasikan sedemikian rupa sehingga setiap pebelajar dapat memilih dan menentukan bahan dan kemajuan belajarnya sendiri. Namun demikian, dalam pelaksanaannya konsep system belajar mandiri tersebut harus dikembangkan berdasarkan ramburambu atau landasan tertentu. Miarso (1996, h.2), menggambarkan landasan-landasan tersebut sebagai berikut:

1) Adanya pilihan materi ajar yang sesuai dengan kebutuhan peserta, dan tersaji dalam aneka bentuk;

2) Pengaturan waktu belajar yang luwes, sesuai dengan kondisi masing-masing; 
3) Kemajuan belajar yang dipantau oleh berbagai pihak yang dapat dilakukan kapan saja;

4) Lokasi belajar yang dipilih atau ditentukan sendiri oleh peserta didik;

5) Dilakukannya diagnosis kemampuan awal dan kebutuhan serta remediasi bila kemampuan itu kurang atau pengecualian bila kemampuannya sudah dikuasai;

6) Evaluasi hasil belajar dilakukan dengan berbagai cara dan bentuk seperti tes penguasaan, tes baku, tes kolokium, pembuatan portofolio, dan sebagainya; dan

7) Pilihan berbagai bentuk kegiatan belajar dan pembelajaran yang sesuai dengan kondisi dan karaktersitik peserta didik maupun karakteristik pelajaran.

Lebih jauh, Miarso (1996, h. 2) menjelaskan komponen sistem belajar mandiri yang meliputi (1) falsafah dan teori; (2) kebutuhan; (3) organisasi; (4) tenaga; (5) prasarana; (6) sarana; (7) bantuan dan pengawasan; (8) kegiatan belajar; dan (9) penilaian dan penelitian. Setiap komponen tersbut merupakan suatu sistem dimana antara yang satu dengan yang lainnya saling berkaitan dan terintegrasi sebagai suatu kesatuan.

Wedemeyer (1968), seperti dikutip oleh Keegan (1990, h. 57) menyebutkan sepuluh karakteristik sistem belajar mandiri. Kesepuluh karakteristik tersebut meliputi: 1) sistem harus dapat dilakukan disemua tempat dimana terdapat pebelajar, walaupun hanya satu orang pebelajar, baik dengan atau tanpa kehadiran guru pada saat dan tempat yang sama; 2) sistem harus memberikan tanggung jawab untuk belajar yang lebih besar kepada pebelajar; 3) sistem harus membebaskan 
anggota fakultas dari tipe tugas lain yang tidak relevan, sehingga lebih banyak waktu digunakan sepenuhnya untuk tugas-tugas pendidikan; 4) sistem harus menawarkan kepada pebelajar pilihan yang lebih luas (lebih banyak peluang) baik dari segi mata kuliah, bentuk, maupun metodologi; 5) sistem harus memanfaatkan, segala bentuk media dan metode pembelajaran yang telah terbukti efektif; 6 ) sistem harus mencampur dan mengkombinasikan media dan metode sehingga setiap topik atau unit dalam suatu mata kuliah diajarkan dengan cara yang terbaik; 7) sistem harus mempertimbangkan desain dan pengembangan mata ajar yang sesuai dengan program media yang sudah ditetapkan; 8) sistem harus memelihara dan meningkatkan peluang untuk dapat beradaptasi dengan perbedaan-perbedaan individu; 9) sistem harus mengevaluasi keberhasilan belajar secara sederhana, dengan tidak harus menjadikan hambatan berkaitan dengan tempat dimana pebelajar belajar, kecepatan belajar mereka, metode yang mereka gunakan atau urutan belajar yang mereka lakukan; dan 10) sistem harus memungkinkan pebelajar untuk memulai, berhenti dan belajar sesuai dengan kecepatanya.

\section{Difusi Inovasi}

a. Pengertian Inovasi

Secara umum, inovasi didefinisikan sebagai suatu ide, praktek atau obyek yang dianggap sebagai sesuatu yang baru oleh seorang individu atau satu unit adopsi lain (Rogers, 1993, h. 12). Thompson dan Eveland (1967) seperti dikutip oleh Rogers (1983, h. 12) mendefinisikan inovasi sama dengan teknologi, yaitu suatu desain yang digunakan untuk tindakan instrumental dalam rangka mengurangi ketidak teraturan suatu hubungan sebab akibat dalam 
mencapai suatu tujuan tertentu. Jadi, inovasi dapat dipandang sebagai suatu upaya untuk mencapai tujuan tertentu. Fullan (1996) seperti dikutip oleh Plomp (1996, h. 273) menerangkan bahwa tahun 1960-an adalah era dimana banyak inovasi-inovasi pendidikan kontemporer diadopsi, seperti matematika, kimia dan fisika baru, mesin belajar (teaching machine), pendidikan terbuka, pembelajaran individu, pengajaran secara team (team teaching) dan termasuk dalam hal ini adalah sistem belajar mandiri.

\section{b. Pengertian Difusi Inovasi}

Difusi didefinisikan sebagai suatu proses dimana suatu inovasi dikomunikasikan melalui saluran tertentu selama jangka waktu tertentu terhadap anggota suatu sistem social (Rogers, 1983, h. 5). Difusi dapat dikatakan juga sebagai suatu tipe komunikasi khusus dimana pesannya adalah ide baru. Disamping itu, difusi juga dapat diangap sebaai suatu jenis perubahan sosial yaitu suatu proses perubahan yang terjadi dalam struktur dan fungsi sistem social (Rogers, 1986, h. 6). Jelas disini bahwa istilah difusi tidak terlepas dari kata inovasi. Karena tujuan utama proses difusi adalah diadopsinya suatu inovasi oleh anggota sistem sosial tertentu. Anggota sistem sosial dapat berupa individu, kelompok informal, organisasi dan atau sub system (Rogers, 1983, h. 24).

c. Unsur-Unsur Difusi Inovasi

Proses difusi melibatkan empat unsur utama, meliputi 1) inovasi; 2) saluran komunikasi; 3) kurun waktu tertentu; dan 4) sistem social (Rogers, 1983, h. 79).

\section{1) Komunikasi dan Salurannya}

Komunikasi adalah proses dimana partisipan menciptakan dan berbagi informasi satu sama lain untuk mencapai suatu pemahaman bersama 
(Rogers, 1983, h. 17). Seperti telah diungkapkan sebelumnya bahwa difusi dapat dipandang sebagai suatu tipe komunikasi khusus dimana informasi yang dipertukarkannya adalah ide baru (inovasi). Dengan demikian, esensi dari proses difusi adalah pertukaran informasi dimana seorang individu mengkomunikasikan suatu ide baru ke seseorang atau beberapa orang lain. Rogers menyebutkan ada empat unsur dari proses komunikasi ini, meliputi: 1) inovasi itu sendiri; 2) seorang individu atau satu unit adopsi lain yang mempunyai pengetahuan atau pengalaman dalam menggunakan inovasi; 3 ) orang lain atau unit adopsi lain yang belum mempunyai pengetahuan dan pengalaman dalam menggunakan inovasi; dan 4) saluran komunikasi yang menghubungkan dua unit tersebut (Rogers, 1983, h. 18). Jadi, dapat disimpulkan bahwa komunikasi dalam proses difusi adalah upaya mempertukarkan ide baru (inovasi) oleh seseorang atau unit tertentu yang telah mempunyai pengetahuan dan pengalaman dalam menggunakan inovasi tersebut (innovator) kepada seseorang atau unit lain yang belum memiliki pengetahuan dan pengalaman mengenai inovasi itu (potential adopter) melalui saluran komunikasi tertentu.

Sementara itu, saluran komunikasi tersebut dapat dikategorikan menjadi dua yaitu: 1) saluran media massa (mass media channel); dan 2) saluran antarpribadi (interpersonal channel) (Rogers, 1983, hal. 18). Media massa dapat berupa radio, televisi, surat kabar, dan lain-lain. Kelebihan media massa adalah dapat menjangkau audiens yang banyak dengan cepat dari satu sumber. Sedangkan saluran antarpribadi melibatkan upaya pertukaran informasi 
tatap muka antara dua atau lebih individu.

\section{2) Waktu}

Waktu merupakan salah satu unsur penting dalam proses difusi. Dimensi waktu, dalam proses difusi, berpengaruh dalam hal: 1) proses keputusan inovasi, yaitu tahapan proses sejak seseorang menerima informasi pertama sampai ia menerima atau menolak inovasi; 2) keinovativan individu atau unit adopsi lain, yaitu kategori relatif tipe adopter (adopter awal atau akhir); dan 3) rata-rata adopsi dalam suatu sistem, yaitu seberapa banyak jumlah anggota suatu sistem mengadopsi suatu inovasi dalam periode waktu tertentu (Rogers, 1983, h. 20).

\section{3) Sistem Sosial}

Sangat penting untuk diingat bahwa proses difusi terjadi dalam suatu sistem sosial. Sistem sosial adalah satu set unit yang saling berhubungan yang tergabung dalam suatu upaya pemecahan masalah bersama untuk mencapai suatu tujuan. Anggota dari suatu sistem sosial dapat berupa individu, kelompok informal, organisasi dan atau sub system (Rogers, 1983, h. 24). Proses difusi dalam kaitannya dengan sistem sosial ini dipengaruhi oleh struktur sosial, norma sosial, peran pemimpin dan agen perubahan, tipe keputusan inovasi dan konsekuensi inovasi (Rogers, 1983, h. 24).

\section{B. METODOLOGI PENELITIAN}

\section{Metode Penelitian}

Sesuai dengan pertanyaan penelitian, maka metode yang tepat untuk penelitian ini adalah studi kasus. Penelitian studi kasus sebagai penelitian empiris yang menyelidiki suatu fenomena 
(gejala) kontemporer dalam konteks senyatanya (real-life) dimana batas-batas antara fenomena dan konteks tersebut masih belum jelas (Yin, 1984, h. 5).

\section{Teknik dan Alat Pengumpulan Data}

Konsekuensi penelitian studi kasus adalah digunakannya berbagai sumber dan teknik pengumpulan data (Yin, 1984, h. 78). Oleh karena itu, penelitian ini menggunakan beberapa teknik pengumpulan data yang meliputi: 1) kuesioner; 2) wawancara; dan 3) analisis dokumen dan arsip.

\section{Subyek Penelitian}

Penelitian ini menggunakan teknik "purposive sampling". Oleh karenanya, terdapat beberapa subyek penelitian yang sengaja dipilih dan ditentukan peneliti sebagai sumber data. Subyeksubyek penelitian tersebut adalah 1) beberapa mahasiswa lulusan PGMKSBM, 2) para tutor/instruktur, 3) para pimpinan dan staff penyelenggara PGMKSBM, dan 4) para inisiator PGMKSBM.

\section{Teknik Analisis dan Keabsahan Data}

Teknik analisis data dalam penelitian ini mengikuti langkah yang disarankan oleh Yin (1984) dan Moleong (2001), yaitu: 1) menelaah seluruh data yang tersedia dari berbagai sumber, dalam hal ini adalah dari hasil wawancara, kuesioner, maupun analisis dokumen; 2) setelah ditelaah maka langkah selanjutnya adalah mengadakan apa yang dinamakan reduksi data yang dilakukan dengan jalan membuat rangkuman yang inti, proses dan pernyataan-pernyataan kunci yang perlu dijaga agar tetap berada didalamnya; 3) langkah berikutnya adalah menyusunnya kedalam satuan-satuan untuk kemudian dikategorisasikan; 4) melakukan pemeriksaan keabsahan data dengan teknik tertentu dan 5) diakhiri dengan penafsiran data. Sementara, pemeriksaan keabsahan data dilakukan melalui triangulasi. 


\section{Waktu dan Tempat Penelitian}

Penelitian ini dilakukan di Universitas Sebelas Maret, Solo dan Propinsi Banten, yang meliputi Kabupaten Serang, Pandeglang dan Lebak. Waktu penelitian dilaksanakan mulai bulan Juli tahun 2002

\section{BAHASAN TEMUAN PENELITIAN}

\section{Rasional Penyelenggaraan PGMKSBM}

Alasan mendasar diselenggarakan PGMKSBM adalah karena tingginya jumlah guru yang telah aktif mengajar tapi belum memenuhi kualifikasi D2. Sementara, penyelenggaraan program penataran penyetaraan guru yang diselenggarakan pemerintah baru mampu menyerap 331.000 orang guru, sekitar 600.000 orang guru lain masih belum memenuhi kualifikasi D2. Para guru yang telah aktif mengajar dan belum memenuhi kualifikasi ini tidak mungkin harus meninggalkan kelas untuk mengikuti program pendidikan peningkatan kjualifikasi secara konvensional. Oleh karena itu, perlu dicarikan inovasi pembelajaran lain dimana mereka dapat meningkatkan kualifikasi tanpa harus meninggalkan kelas. Alasan inilah yang melandasi diselenggarakannya inovasi PGMKSBM.

Peluang penyelenggaraan inovasi PGMKSBM ini tidak mendapatkan kesulitan karena didukung oleh adanya landasan hukum (konstitusional) yang memungkinkan diselenggarakannya program pembelajaran alternatif untuk meningkatkan kualifikasi guru. Landasan hukum tersebut antara lain adalah Garis-Garis Besar haluan Negara (GBHN) tahun 1993, pasal 31 Peraturan Pemerintah No. 38/1992 tentang Tenaga Kependidikan dan SK Mendikbud No. 0854/U/1989 tanggal 30 Desember 1989 yang mempersyaratkan guru SD berkualifikasi minimal D2. Sebagai tindak lanjut dari SK Mendikbud ini, pada tanggal 12 Juni 1996, Universitas Sebelas Maret dan Pusat Pengembangan Penataran Guru Tertulis Bandung menandatangani naskah kesepahaman bersama (MoU) untuk melaksanakan pola alternatif penataran guru 
pendidikan dasar di lingkungan Depdikbud.

Salah satu syarat suatu inovasi adalah benar secara konseptual (conceptually correct). penyelenggaraan PGMKSBM juga didasarkan atas landasan konsep yang jelas. Dokumen yang ada tentang PGMKSBM menunjukkan bahwa terdapat empat pendekatan/paradigma yang digunakan sebagai landasan penyelenggaraan PGMKSBM, yaitu pendekatan pembelajaran reflektif, pendekatan pembelajaran kolaboratif, pendekatan pembelajaran konstruktif, dan pendekatan penelitian tindakan kelas.

\section{Pengertian PGMKSBM}

Berdasarkan data temuan penelitian dapat disimpulkan bahwa yang dimaksud dengan Pendidikan Guru Model Kualifikasi dengan Sistem Belajar Mandiri (PGMKSBM) adalah suatu inovasi pendidikan yang bertujuan untuk meningkatkan kualifikasi guru, bagi guru yang sedang berstatus aktif mengajar tapi belum memenuhi kualifikasi yang dipersyaratkan dengan tanpa harus meninggalkan pekerjaanya. Dengan pengertian ini, maka PGMKSBM dapat dikatakan sebagai program dalam jabatan (in-service). Artinya, program ini tidak berlaku bagi guru dalam status yang tidak aktif mengajar. Seperti digambarkan dalam bab sebelumnya, jelas sekali ditunjukkan bahwa antecedant program PGMKSBM adala para guru yang sedang aktif mengajar. Guru yang sedang aktif mengajar ini mengikuti proses pembelajaran yang dinamakan PGMKSBM yang mengoptimalkan pengetahuan bawaaan, pengalaman, dan lingkungan. Tujuannya adalah meningkatnya kinerja guru dan hasil belajar.

Dengan demikian, dapat disimpulkan bahwa karakteristik dari PGMKSBM adalah bahwa 1) PGMKSBM bukan program prajabatan (pre-service training) tapi program dalam jabatan (in-service training); 2) PGMKSBM tidak menitikberatkan pada tatap muka, tapi pada belajar mandiri dalam bentuk tugas-tugas 
yang diintegrasikan dengan tugas keseharian mengajar di sekolah; 3) PGMKSBM menerapkan pendekatan "collaborative action research" yaitu mensinergikan antara teori ke dalam praktek mengajar sehari-hari; 4) sumber penilaian diperoleh tidak hanya dari ujian tengah dan kahir semester, tapi juga dari portfolio dalam bentuk laporan mingguan dan bulanan; dan 5) teman sejawat dan kepala sekolah menjadi salah satu sumber dan mitra belajar.

\section{Sejarah Singkat PGMKSBM}

Temuan penelitian menunjukkan bahwa sebenarnya cikal bakal PGMKSBM telah muncul sejak tahun 1994. Pada bulan September 1994, Puslitbangjari UNS mengembangkan model penataran terakreditasi dengan sistem belajar mandiri untuk membantu meningkatkan profesionalitas guru dengan memanfaatkan forum PKG/KKG dan MGMP di Kecamatan Pasarkliwon. Tujuannya adalah untuk meningkatkan kualifikasi guru, bagi guru-guru yang sudah mengajar akan tetapi belum memenuhi kualifikasi yang dipersyaratkan. Pada tahap ini, belum terpikirkan kerjasama dengan pihak Departemen Pendidikan. Program ini dilakukan hanya sebagai bentuk kegiatan pengabdian kepada masyarakat yang diberikan oleh Puslitbangjari UNS. Kanwil Departemen Pendidikan dan Kebudayaan Propinsi Jawa Tengah pada saat itu hanya sebatas mengetahui.

Model tersebut menggunakan pendekatan collaborative action research (CAR) dengan sistem belajar mandiri. Yang dimaksud dengan collaborative action research adalah sebagai berikut: 1) setiap guru anggota gugus membuat rancangan pembelajaran; 2) rancangan pembelajaran tersebut diterapkan di kelas dan diamati oleh teman sejawat; 3) hasil pengamatan didiskusikan dengan teman sejawat dan nara sumber (dosen kunjung) pada setiap hari Sabtu siang setelah akhir jam belajar; 4) permasalahan yang tidak dapat dipecahkan dalam diskusi diangkat sebagai materi penataran; 5) materi penataran disajikan oleh nara sumber 
(dosen kunjung) dari UNS dengan metode diskusi; 6) berdasarkan hasil diskusi pada point 5, guru memperbaiki/menyempurnakan rancangan pembelajarannya; dan 7) rancangan pembelajaran diterapkan kembali di kelas dan diamati oleh teman sejawat. Begitu seterusnya, ketujuh tahapan ini menjadi siklus yang berulangulang.

Pada saat bersamaan, di akhir tahun 1995, ketika Puslitbangjari UNS menyelenggarakan penataran guru terakreditasi di Kecamatan Pasarkliwon, Pusat Pengembangan Penataran Guru Tertulis Bandung, melalui Prof. Dr. Yusufhadi Miarso, menjajaki kemungkinan kerjasama dengan Puslitbangjari UNS dalam hal mencari model pembelajaran yang inovatif dengan berbasiskan sistem belajar mandiri. Model pembelajaran ini diharapkan mampu membantu menuntaskan program penyetaraan D2 bagi 600.000 guru yang belum berkualifikasi setara D2 di seluruh Indonesia. Program pendidikan yang ada baru berhasil menyerap 2000 guru dan akan memakan waktu 30 tahun untuk menuntaskan ke-600.000 guru tersebut jika tidak ditemukan alternatif model pembelajaran lain. Beberapa pertemuan dilakukan, (lihat tabel 6) sehingga pada bulan Juni 1996 dicapai suatu perjanjian kerjasama antara P3GT Bandung dengan UNS untuk menyelenggarakan suatu uji coba model pembelajaran yang dinamakan Penataran Guru Terakreditasi Model Kualifikasi dengan Sistem Belajar Mandiri (PGTMKSBM). Pada saat itu disepakati pembagian kewenangan, sebagai berikut: 1) P3GT Bandung sebagai penyandang dana uji coba; 2) Puslitbangjari UNS sebagai pengembang model; dan 3) FKIP UNS sebagai penanggung jawab akreditasi bidang akademik.

Bulan Februari sampai dengan akhir Juli 1997, dilakukan uji coba tahap I terhadap 100 orang peserta dari Jawa Tengah dan 100 orang peserta dari Jawa Barat. Hasil uji coba ini dijadikan sebagai bahan penyempurnaan model. Pada bulan September 1997 sampai dengan akhir Januari 1998, dilaksanakan uji coba tahap II. Uji coba tahap kedua ini 
melibatkan kurang lebih 1800 orang peserta yang tersebar di wilayah Jawa Tengah dan Jawa Barat.

Pada saat tahap uji coba 2 masih berlangsung, tanggal 3 Agustus 1997, Kanwil Depag Jawa Barat melakukan kajian tentang model Penataran Guru Terakreditasi Model Kualifikasi dengan Sistem Belajar Mandiri ke P3GT Bandung. Pengkajian dilaksanakan di Lembang Bandung. Sebagai tindak lanjut dari pertemuan tersebut, Kanwil Depag Jawa Barat didampingi P3GT Bandung ng ke UNS untuk menjajaki kemungkinan kerjasama perluasan penataran di lingkungan Departemen Agama Jawa Barat. Akhirnya di sepakati kerjasama antara UNS dengan Kanwil Depag Jawa Barat untuk memperluas penyelenggaraan penataran ke wilayah Banten (sekarang Propinsi). Kerjasama dengan Depag ini bertujuan untuk meningkatkan kualifikasi guru Madrasah Ibtidaiyah (D2) dan Madrasah Tsanawiyah (D3) untuk guru mata pelajaran Matematika, Fisika, Biologi dan Bahasa Inggris.

Pada tahap ini, pelaksanaannya tidak lagi melalui tahapan penataran, sehingga tidak lagi melibatkan P3GT Bandung. Namanya berubah menjadi Pendidikan Guru Model Kualifikasi dengan Sistem Belajar Mandiri (PGMKSBM). Program D2 dimulai pada bulan September 1997 dan berakhir pada tahun 1999 melalui dua tahapan wisuda. Wisuda tahap I dilakukan pada 19 Juni 1999 dan wisuda tahap II dilakukan pada tanggal 13 Nopember 1999.

Pelaksanaan program D3 dimulai pada bulan Desember 1997 dan berakhir pada tanggal 14 April 2001. Sejak tahun 2001 sampai penelitian ini dilakukan, kerjasama antara UNS dengan P3GT Bandung, Kanwil Departemen Agama Jawa Barat dan atau instansi lain masih berlangsung. Namun, mengingat penelitian ini dibatasi hanya sampai pelaksanaan PGMKSBM di wilayah Banten, maka sejarah PGMKSBM pasca tahun 2001 tidak dapat dijelaskan dalam penelitian ini. 


\section{Difusi Inovasi PGMKSBM}

Temuan penelitian menunjukkan bahwa difusi inovasi PGMKSBM terjadi dalam suatu lembaga (organisasi). Artinya PGMKSBM diadopsi oleh suatu unit adopsi, yaitu organisasi bukan individu. Dalam konteks penelitian ini, organisasi yang mengadopsi inovasi PGMKSBM tersebut adalah Pusat Pengembangan Penataran Guru Tertulis Bandung dan Kantor Wilayah Departemen Agama Jawa Barat. Saluran komunikasi yang digunakan selama proses difusi inovasi PGMKSBM adalah saluran komunikasi antar pribadi dalam bentuk pertemuan, kunjungan, seminar dan lokakarya.

Apabila dilihat dari sisi waktu maka perintisan PGMKSBM antara UNS dan P3GT Bandung terjadi selama 4 bulan. Pertemuan pertama antara Puslitbangjari UNS dengan P3GT Bandung terjadi pada bulan Maret 1996 dan penanda tanganan kerjasama terjadi pada bulan Juni 1996. Namun, demikian proses difusi inovasi PGMKSBM antara UNS dengan P3GT Bandung untuk melaksanakan kualifikasi guru setara D2 melalui PGMKSBM, sampai penelitian ini dilakukan masih terus berjalan. Sementara itu difusi inovasi PGMKSBM oleh UNS dan P3GT Bandung terhadap Kanwil Depag Jawa Barat memakan waktu selama 18 bulan (1,5 tahun), yaitu dari bulan Maret 1996 - Agustus 1997. Pelaksanaan PGMKSBM kerjasama antara UNS, P3GT Bandung dan Kanwil Depag Jawa Barat untuk program D2 dan D3 di wilayah Banten berakhir pada bulam Pebruari 2001. Sejak tahun 2001, adopsi inovasi PGMKSBM untuk program D2 dan D3 bagi guru-guru MI dan MTs di wilayah Banten tidak berlanjut (discontinuance).

\section{Tahapan Keputusan Adopsi Inovasi PGMKSBM}

Rogers (1984), menjelaskan bahwa tahapan keputusan adopsi inovasi terjadi dalam 5 tahap, yaitu: (1) tahap pencanangan; (2) tahap pencocokan; (3) tahap redefinisi/restrukturisasi; (4) tahap klarifikasi; dan (5) tahap rutinisasi. Temuan penelitian 
menunjukkan bahwa sebenarnya proses difusi inovasi terjadi pada dua organisasi, yaitu (1) antara Puslitbangjari UNS dengan P3GT Bandung; dan 2) antara Pusltibangjari UNS dengan Kanwil Departemen Agama Jawa Barat. Tahapan keputusan adopsi inovasi PGMKSBM dalam masing-masing isntitusi tersebut dapat dijelaskan sebagai berikut:

\section{a. Tahapan Keputusan Adopsi Inovasi PGMKSBM oleh P3GT Bandung}

Tahap keputusan adopsi inovasi PGMKSBM oleh P3GT Bandung hanya terjadi sampai tahap klarifikasi. Adopsi PGMKSBM tidak terjadi sampai tahap rutinisasi. Secara lebih rinci keputusan adopsi inovasi PGMKSBM oleh P3GT Bandung dapat dijelaskan sebagai berikut:

- Tahap 1: Pencanangan Agenda (Agenda Setting). Pencanangan agenda oleh P3GT Bandung didorong oleh adanya kebutuhan bahwa P3GT Bandung membutuhkan inovasi pendidikan yang dapat membantu meningkatkan kualifikasi bagi 600.000 guru se-Indonesia yang sudah mengajar tapi belum memenuhi kualifikasi D2. Jika dilakukan dengan pola pendidikan konvensional akan memakan waktu kurang lebih 30 tahun lamanya. Prof. Yusufhadi Miarso, M.Sc. yang pada waktu itu berperan sebagai konsultan P3GT Bandung mengusulkan pihak P3GT untuk bertemu dengan pihak Puslitbangjari UNS. Puslitbangjari UNS adalah lembaga penelitian yang telah lama mengembangkan model pendidikan dengan sistem belajar mandiri. Pada saat bersamaan, Puslitbangjari UNS saat itu sedang merintis model Penataran Guru Terakreditasi dengan Sistem Belajar Mandiri di Kecamatan Pasarkliwon (lihat sejarah singkat PGMKSBM).

- Tahap 2: Pencocokan (Matching). Upaya pencocokan kebutuhan akan model pendidikan alternatif yang inovatif ke Puslitbangjari UNS dilakukan dengan 
kunjungan. Seperti terlihat dalam tabel 6, pertemuan terjadi dua kali. Pertemuan pertama dilakukan pada tanggal 29 Maret 1996 untuk menjajaki kemungkinan dilakukannya kerjasama. Pertemuan kedua dilakukan pada tanggal 26 April 1996 yang berhasil menyusun kerangka operasional program penyetaraan D2 dengan sistem belajar mandiri. Selanjutnya keputusan untuk mengadopsi model penataran dengan sistem belajar mandiri terjadi dengan ditanganinya naskah perjanjian kerjasama antara P3GT Bandung dengan UNS pada bulan Juni 1996.

- Tahap 3: Redefinisi/Restrukturisasi. Restrukturisasi / redefinisi dilakukan dengan cara melakukan lokakarya dan penyusunan paket ajar dan pengakreditasiannya. Lokakarya pertama dilakukan pada tanggal 18 sampai dengan 21 Nopember 1996. Lokakarya tersebut menghasilkan model penataran yang dinamakan dengan Penataran Guru Terakreditasi Model Kualifikasi dengan Sistem Belajar Mandiri (PGTMKSBM) beserta perangkatnya yang meliputi: deskripsi program $\mathrm{D} 2$, dan silabi/GBPP untuk semester I. Penyusunan paket pembelajaran dilakukan mulai bulan Oktober s/d Desember 1996 dan menghsilkan paket pembelajaran untuk mata tataran: kependidikan, Pendidikan IPA, Pendidikan Matematika 1, Pendidikan IPS 1, Olah Raga dan Kesehatan, PPkn 1 dan Bahasa Indonesia.

- Tahap 4: Klarifikasi. Klarifikasi dilakukan dengan cara melaksanakan uji coba. Uji coba tahap 1 dilakukan mulai 1 Februari s/d 31 Juli 1997 di Jawa Barat dan Jawa Tengah dengan melibatkan masing-masing 100 orang peserta. Kemudian, hasil ujicoba tahap 1 diseminarkan untuk disempurnakan pada bulan April 1997. Sementara peserta uji coba tahap 1 memasuki semester 2, uji coba tahap 2 dilakukan mulai 1 September 1997 s/d 30 Januari 1998. Kali ini melibatkan peserta yang lebih banyak, 1800 orang 
peserta yang tersebar di wilayah Jawa Tengah dan Jawa Barat. Setelah tahap ini belum masuk ke tahap rutinisasi.

b. Tahapan Keputusan Adopsi Inovasi PGMKSBM oleh Kanwil Depag Jawa barat

Tahap keputusan adopsi inovasi PGMKSBM oleh Kanwil Depag Jawa Barat terjadi sampai tahap terakhir, yaitu tahap rutinisasi. Penjelasan lebih rinci dapat digambarkan sebagai berikut:

- Tahap 1: Pencanangan Agenda (Agenda Setting). Pencanangan agenda adopsi PGMKSBM oleh Kanwil Depag Jawabarat terjadi pada tahun 1997 yang didorong oleh adanya kenyataan bahwa hampir sebagian besar guru-guru Madrasah Ibtidaiyah (MI) dan Madrasah Tsanawiyah (MTs) di lingkungan Departemen Agama Jawa Barat belum memenuhi kualifikasi D2. Kanwil Departemen Agama pada saat itu memandang perlu adanya suatu model pendidikan yang dapat memecahkan masalah tersebut secara efektif dan efisien.

- Tahap 2: Pencocokan (Matching). Tahap pencocokan dilakukan melalui dua kegiatan. Pertama, Kanwil Depag Jawa Barat pada bulan Agustus 1997 menngi P3GT Bandung untuk melakukan pengkajian terhadap PGTMKSBM yang sedang diuji cobakan oleh P3GT Bandung dan UNS di Propinsi Jawa Tengah. Pertemuan ini menghasilkan kesepakatan dimana pihak Kanwil Depag bersama dengan P3GT Bandung bersedia untuk berkunjung ke UNS dalam rangka menjajaki kemungkinan kerjasama melakukan perluasan penataran di lingkungan Kanwil Depag Jawa Barat. Selanjutnya, pada tanggal 29 Agustus 1997, Kanwil Depag Jawa Barat bersama-sama dengan P3GT Bandung berkunjung ke UNS untuk membahas kemungkinan kerjasama. Hasil dari pertemuan ini 
adalah kesediaan UNS untuk memperluas penataran di lingkungan Kanwil Depag Jawa Barat.

- Tahap 3: Redefinisi/Restrukturisasi. Pada tahap ini terjadi dua bentuk redefinisi/strukturisasi. Pertama, restrukturisasi PGMKSBM untuk program D2 dilakukan dengan cara melakukan analisis kurikulum D2 Pendidikan Agama Islam dan penyusunan deskripsi program kualifikasi. Kegiatan ini terjadi pada bulan Agustus sampai dengan September 1997. Kedua, restrukturisasi PGMKSBM untuk program D3 mata pelajaran Biologi, Fisika, Matematika dan Bahasa Inggris. Inti dari restrukturisasi untuk program D3 ini adalah melakukan persiapan untuk program D3. Kegiatan yang dilakukan adalah: 1) melakukan rapat persiapan pertama antara Puslitbangjari dan fungsionaris FKIP UNS mengenai persiapan pelaksanaan program D3 (13 September 1997); 2) melakukan rapat persiapan kedua dalam rangka mempersiapkan loka karya penyusunan kurikulum untuk program D3 (20 September 2003); 3) melakukan pralokakarya pengembangan kurikulum dan identifikasi calon penulis paket pembelajaran (27 September 1997); dan 4) melaksanakan loka karya penyusunan GBPP/Silabi dan Paket Pembelajaran (29 - 30 September 1997).

- Tahap 4: Klarifikasi. Pada tahap ini terjadi tiga tahap pelaksanaan PGMKSBM. Pertama, pelaksanaan uji coba tahap 1 untuk program D2 sebanyak 100 orang peserta dari Jawa Barat (Februari - Juli 1997). Kedua, sementara peserta uji coba tahap 1 memasuki semester II, uji coba tahap 2 untuk program D2 mulai memasuki semester I (September 1997 - Januari 1998). Terakhir, pelaksanaan semester I untuk program D3 (Desember 1997 - Juni 1998).

- Tahap 5: Rutinisasi. Pada tahap ini, program D2 dan D3 terus dilanjutkan. Pada tahun 1999 kedua program 
tersebut untuk wilayah Banten berakhir. Namun demikian, kerjasama antara UNS dan Depag di wilayah lain di Indonesia berlanjut. Begitu pula halnya dengan kerjasama antara P3GT dengan UNS dan P3GT dengan LPTK lain di wilayah lain di Indonesia juga berlanjut.

\section{Keberhasilan PGMKSBM di Propinsi Banten}

Keberhasilan PGMKSBM di Propinsi Banten dapat dilihat dari berbagai segi: 1) kuantitas lulusan; 2); peningkatan penguasaan materi 3) peningkatan kinerja peserta; dan 4) peningkatan hasil belajar siswa.

\section{a. Peningkatan Jumlah Guru Berkualifikasi}

Hasil analisis dokumen dan arsip menunjukkan bahwa program D2 PGMKSBM telah meluluskan 590 peserta $(92,2 \%)$ dari total peserta sebanyak 640 orang. Sedangkan untuk program D3 telah meluluskan 329 (94,54\%) dari 348 peserta secara keseluruhan. Hal ini menunjukkan bahwa tingkat kelulusan program PGMKSBM di Propinsi Banten dapat dikatakan tinggi. Sementara itu, prosentase kelulusan tertinggi terjadi pada program studi D3 IPA. Prosentase kelulusan terendah terjadi pada program studi D3 Bahasa Inggris. Jumlah guru MI yang berkualifikasi D2 setelah adanya PGMKSBM secara keseluruhan meningkat menjadi $42,69 \%$. Artinya, mengalami kenaikan sebesar $21,29 \%$ dari sebelumnya yang hanya sebesar $21,14 \%$. Sementara itu, untuk guru MTs yang berkualifikasi D3 setelah adanya PGMKSBM meningkat menjadi $54,67 \%$ yang berarti mengalami peningkatan sebesar $15,22 \%$ dari sebelumnya yang hanya sebesar $39,45 \%$.

\section{b. Peningkatan Penguasaan Materi}

Hasil analisis dokumen menunjukkan bahwa peningkatan penguasaan materi bervariasi antara $18,15 \%$ sampai dengan 35,50 . Secara kumulatif, rata-rata penguasaan 
materi peserta sebelum mengikuti PGMKSBM adalah 46,70\%. Setelah mengikuti PGMKSBM meningkat 25,99\% menjadi $72,69 \%$. Untuk program studi D2, rata-rata penguasaan materi sebelum PGMKSBM sebesar 53,33\%. Setelah mengikuti PGMKSBM, rata-rata penguasaan materi meningkat $22,47 \%$ menjadi $75,80 \%$. Secara lebih rinci, penguasaan materi untuk mata kuliah kependidikan atau proses belajar mengajar meningkat $18,90 \%$. Untuk mata kuliah kelompok bidang studi sosial dan bahasa meningkat $27 \%$ dan untuk mata kuliah kelompok bidang studi eksakta/ MIPA meningkat 21,50\%. Untuk program studi D3 IPA, ratarata penguasaan materi sebelum PGMKSBM sebesar $39 \%$. Setelah mengikuti PGMKSBM rata-rata penguasaan materi meningkat $30,77 \%$ menjadi $69,77 \%$. Sementara itu, Penguasaan materi untuk mata kuliah kependidikan atau proses belajar mengajar meningkat $21,50 \%$. Untuk mata kuliah kelompok bidang studi Biologi meningkat 35,30\% dan untuk mata kuliah bidang studi Fisika meningkat $35,50 \%$.

\section{c. Peningkatan Kinerja}

Berdasarkan jejak pendapat yang dilakukan oleh pihak UNS terhadap Kepala Sekolah ( $N=100)$, 93\% menyatakan bahwa pendidikan yang ditempuh dengan program PGMKSBM berpengaruh positif terhadap kinerja guru, 13 $\%$ menyatakan kadang-kadang mengganggu kegiatan sekolah, dan $89 \%$ menyatakan meningkatkan kemampuan mengajar.

Berdasarkan data hasil analisis terhadap kuesioner menunjukkan bahwa manfaat program PGMKSBM terhadap pekerjaan guru di lapangan secara berturut-turut adalah: 1) peningkatan dalam penguasaan akan materi mengajar; 2) peningkatan dalam penguasaan metodologi mengajar; 3) perubahan dalam cara/kebiasaan mengajar; 3) peningkatan dalam disiplin kerja; 4) peningkatan dalam 
kebiasaan berdiskusi.memcahkan masalah mengajar; 5) keterbukaan dalam berpikir dan menerima pendapat orang; dan 6) peningkatan dalam kebiasaan membaca.

\section{d. Peningkatan Hasil Belajar Siswa}

Berdasarkan hasil EBTA/EBTANAS yang dicapai oleh sekolah yang gurunya mengikuti program PGMKSBM menunjukkan adanya pengaruh terhadap peningkatan nilai rata-rata EBTA/EBTANAS dari tahun ke tahun. Dari tahun 1996 (sebelum PGMKSBM) sampai dengan tahun 2000 (ketika PGMKSBM), Madrasah Ibtidaiyah mengalami ratarata peningkatan nilai EBTANAS sebesar 1,83. sedangkan untuk Madrasah Tsanawiyah mengalami rata-rata peningkatan sebesar 1,01.

\section{Faktor Pendukung dan Penghambat PGMKSBM}

\section{a. Faktor Pendukung}

Temuan penelitian menunjukkan dengan jelas bahwa faktor utama pendukung keberhasilan PGMKSBM di Propinsi Banten adalah karakteristik dari inovasi PGMKSBM itu sendiri, yang meliputi: 1) PGMKSBM relatif lebih unggul dibandingkan dengan pola pendidikan konvensional; 2) PGMKSBM sesuai dengan kondisi (compatible) dan kebutuhan guru di lingkungan Departemen Agama wilayah Banten; dan 3) pola belajar melalui PGMKSBM cukup luwes (flexible), peserta dapat belajar mandiri secara individu maupun keompok sesuai dengan kondisi yang dihadapinya kapan saja dan dimana saja. Kedua, adalah adanya dukungan dana dan kebijakan. Departemen Agama pada saat itu memperoleh bantuan dana pinjaman dari Bank Dunia dan mengeluarkan kebijakan kerjasama penyelenggaran program penyetaraan guru sehingga PGMKSBM tersebut dapat terselenggara dan peserta mengikutinya tanpa dipungut biaya. Terakhir adalah adanya dukungan pengalaman dari penyelenggara. PGMKSBM dikelola oleh institusi pengembang pendidikan dengan 
sistem belajar mandiri, yaitu Pusat Penelitian dan Pengembangan Belajar Mandiri (PUSLITBANGJARI) Universitas Sebelas Maret. Puslitbangjari UNS adalah satusatunya institusi yang khusus meneliti dan mengembangkan penerapan sistem belajar mandiri di Indonesia.

\section{b. Faktor Penghambat}

Ada beberapa faktor penghambat keberhasilan penyelenggaraan PGMKSBM di Propinsi Banten. Faktorfaktor penghambat penyelenggaraan PGMKSBM di Propinsi Banten tersebut meliputi: (1) ketidaksamaan persepsi terhadap sistem belajar mandiri dan pelaksanaannya antara pihak terkait (stakeholders); (2) rendahnya motivasi belajar (kesiapan belajar mandiri); (3) jarak dan biaya transportasi untuk pergi dan pulang dari dan ke lokasi diskusi kelompok dan kuliah tatap muka; (4) ketidak sesuaian latar belakang pendidikan dan mata pelajaran yang diampu dengan program studi yang diikuti; (5) rendahnya kualitas bahan belajar; dan (6) pengelolaan PGMKSBM secara keseluruhan.

\section{KESIMPULAN, IMPLIKASI DAN SARAN \\ 1. Kesimpulan}

Kesimpulan yang dapat diambil sebagai hasil dari penelitian ini antara lain adalah sebagai berikut:

a. Pendidikan Guru Model Kualifikasi dengan Sistem Belajar Mandiri adalah suatu program pendidikan dalam jabatan (in-service training) yang bertujuan untuk meningkatkan kualifikasi guru (D2 dan D3), bagi guru yang sedang berstatus aktif mengajar tapi belum memenuhi kualifikasi yang dipersyaratkan dengan tanpa harus meninggalkan pekerjaanya.

b. PGMKSBM memiliki karakteristik sebagai berikut:

1) PGMKSBM bukan program prajabatan (pre-service training) tapi program dalam jabatan (in-service 
training);

2) PGMKSBM tidak menitikberatkan pada tatap muka, tapi pada sistem belajar mandiri dalam bentuk tugas-tugas yang diintegrasikan dengan tugas keseharian mengajar di sekolah;

3) PGMKSBM menerapkan pendekatan "reflective \& collaborative action research" yaitu mensinergikan antara teori ke dalam praktek mengajar sehari-hari;

4) Sumber penilaian diperoleh tidak hanya dari ujian tengah dan akhir semester, tapi juga dari portfolio dalam bentuk laporan mingguan dan bulanan; dan

5) Teman sejawat dan kepala sekolah menjadi salah satu sumber dan sekaligus sebagai mitra belajar.

c. PGMKSBM diselenggarakan atas dasar adanya kebutuhan pemerintah untuk meningkatkan kualifikasi guru yang sedang dalam status mengajar tapi belum memenuhi kualifikasi yang dipersyaratkan melalui model pendidikan non-konvensional yang memungkinkan para guru tersebut dapat menyelesaikan program pendidikan tanpa harus meninggalkan tugas mengajar sehari-hari.

d. PGMKSBM telah berhasil meningkatkan jumlah guru berkualifikasi D2 sebesar 21,29\% dan guru berkualifikasi D3 sebesar 15,22\% di Propinsi Banten. Disamping itu, PGMKSBM juga telah memberikan kontribusi terhadap: (1) peningkatan penguasaan materi para guru; (2) peningkatan kinerja di sekolah; dan (3) peningkatan hasil belajar siswa.

e. Difusi inovasi PGMKSBM terjadi pada tingkat organisasi (khususnya UNS, P3GT Bandung dan Kanwil Depag Jawa Barat) melalui saluran komunikasi antarpribadi (seperti pertemuan/rapat, kunjungan, seminar dan lokakarya).

f. Faktor pendukung keberhasilan PGMKSBM di Propinsi Banten adalah sebagai berikut:

1) Karakteristik dari inovasi PGMKSBM itu sendiri, yang meliputi: 1) PGMKSBM relatif lebih unggul dibandingkan dengan pola pendidikan konvensional; 2) PGMKSBM sesuai dengan kondisi (compatible) dan kebutuhan guru 
di lingkungan Departemen Agama wilayah Banten; dan 3) pola belajar melalui PGMKSBM cukup luwes (flexible), peserta dapat belajar mandiri secara individu maupun keompok sesuai dengan kondisi yang dihadapinya kapan saja dan dimana saja.

2) Adanya dukungan dana dan kebijakan, khususnya dari Deaprtemen Agama.

3) Dukungan pengalaman dari pengelola yaitu Univrsitas Sebelas Maret (UNS).

g. Faktor-faktor penghambat keberhasilan PGMKSBM di Propinsi Banten adalah sebagai berikut:

1) program PGMKSBM masih dalam tahap percobaan (belum menjadi suatu model yang siap didiseminasikan), ketika diadopsi untuk meningkatkan kualifikasi guru Madrasah Ibtidaiyah dan Madrasah Tsanawiyah di Propinsi Banten;

2) ketidaksamaan persepsi dan sikap terhadap sistem belajar mandiri antara semua pihak terkait (stakeholders);

3) rendahnya motivasi belajar dan kesiapan belajar mandiri mahasiswa;

4) jarak dan biaya transportasi untuk pergi dan pulang dari dan ke lokasi diskusi kelompok dan kuliah tatap muka;

5) ketidak sesuaian latar belakang pendidikan, mata pelajaran yang diampu di kelas dan program studi yang diambil;

6) rendahnya kualitas bahan belajar; dan

7) lemahnya pengelolaan secara keseluruhan.

\section{Implikasi}

PGMKSBM terbukti telah berhasil diselenggarakan untuk meningkatkan kualifikasi guru di Propinsi Banten. Hal ini membuktikan bahwa sistem belajar mandiri dapat diterapkan untuk memecahkan masalah peingkatan kualifikasi guru, khususnya bagi guru yang sedang dalam status aktif mengajar, sehingga mereka dapat belajar sambil tetap mengajar atau sebaliknya tetap mengajar sambil belajar. 
Masalah peningkatan mutu pendidikan, sampai saat ini masih menjadi salah satu isu strategis kebjikan pendidikan nasional, selain pemerataan dan perluasan akses serta pencitraan publik dan tata kelola. Upaya peningkatan mutu pendidikan, salah satunya dapat dilakukan melalui peningkatan kualifikasi guru. Sampai saat ini, dari 3,31 juta guru yang tersebar di seluruh Indonesia, sekitar $50 \%$ lebih guru yang sudah aktif mengajar tapi masih belum memenuhi kualifikasi. Pendekatan pendidikan untuk meningkatkan kualifikasi guru dengan cara konvensional tidak mungkin dapat memecahkan masalah tersebut. Model pendidikan dengan sistem belajar mandiri, seperti PGMKSBM, merupakan salah satu alternatif solusi yang tepat untuk memecahkan masalah tersebut. PGMKSBM sebagai salah satu model inovasi pendidikan layak untuk diadopsi dan dimodifikasi untuk memecahkan masalah peningkatan kualifikasi guru, khususnya atau untuk kebutuhan peningkatan pengetahuan dan keterampilan tertentu melalui pelatihan/penataran dengan sistem belajar mandiri.

Pendidikan dengan sistem belajar mandiri akan menjadi trend model pendidikan masa depan. Oleh karenanya perlu terus dikembangkan, terutama dengan mengintegrasikan teknologi informasi dan komunikasi yang dewasa ini berkembang dengan pesat. Sebagai contoh, pendidikan dengan sistem belajar mandiri yang tidak hanya memanfaatkan bahan belajar cetak, tapi terintegrasi dengan audio/radio, video/televisi dan bila perlu secara online melalui internet.

\section{Saran}

Mengacu kepada temuan tentang faktor-faktor pendukung dan penghambat penyelenggaraan PGMKSBM seperti tersebut di atas, maka saran-saran yang dapat diajukan adalah sebagai beirkut:

a. Salah satu faktor pendukung keberhasilan pelaksanaan program PGMKSBM adalah adanya kebijakan dan dana. Oleh karena itu, untuk memecahkan masalah yang sama 
Pemerintah hendaknya dapat mengeluarkan kebijakan yang secara khusus mengatur tentang penyelenggaraan pendidikan untuk meningkatkan kulaifikasi guru dengan menerapkan sistem belajar mandiri. Fakta menunjukkan lebih dari 1 juta guru yang tersebar di Indonesia dan berstatus aktif mengajar belum memenuhi kualifikasi seperti yang dipersaratkan.

b. PGMKSBM sebagai suatu model hendaknya diuji cobakan terlebih dahulu dengan seksama sebelum didiseminasikan untuk memecahkan masalah kualifikasi guru.

c. Pengelolaan yang lemah seperti tersebut di atas, khususnya dari sisi tenaga merupakan salah salah satu faktor penghambat penyelenggaraan PGMKSBM. Oleh karena itu, penyelenggaraan PGMKSBM atau model pendidikan serupa perlu ditunjang oleh adanya tenaga pengelola yang terdidik dan memiliki keterampilan khusus tentang pengelolaan pendidikan dengan sistem belajar mandiri.

d. Rendahnya kualitas bahan belajar ternyata berpengaruh terhadap motivasi dan hasil belajar. Oleh karena itu, mengingat program pendidikan ini menggunakan sistem belajar mandiri, maka bahan belajar hendaknya dikembangkan sedemikian rupa secara khusus sebagai bahan belajar mandiri (self-paced learning materials). Disamping itu, bahan belajar cetak hendaknya tidak dijadikan sebagai satu-satunya sumber belajar, tapi perlu ditunjang dengan sumber belajar lain sesuai dengan prinsip belajar berbasis aneka sumber (resources-based learning) seperti video, audio-cassette atau bila memungkinkan memanfaatkan web atau internet.

e. Kesiapan belajar mandiri (independent learning readiness) adalah mutlak adanya dalam pembelajaran dengan sistem belajar mandiri. Oleh karena itu, sebelum program dimulai sebaiknya peserta dikondisikan dan diberikan orientasi terlebih dahulu tentang belajar mandiri. 
f. Ketidak sesuaian antara program studi yang diambil dengan latar belakang pendidikan serta mata pelajaran yang diampu berpengaruh terhadap kegagalan penyelesaian studi. Oleh karena itu, program studi yang diambil oleh peserta hendaknya sesuai dengan latar belakang pendidikan sebelumnya dan mata pelajaran yang diampu. Hal ini, dapat diatasi melalui proses seleksi yang ketat.

g. Materi kuliah yang bersifat teoretis juga menjadi factor penghambat. Oleh karena itu, materi sebaiknya kontemporer seperti terkait dengan problem-based learning, contextual teaching and learning, active learning, dan lain-lain serta dirancang sedemikian rupa sehingga lebih bersifat praktis, kontekstual, disertai dengan contoh atau demonstrasi yang kongkrit. Oleh karena itu, point 4 seperti disebutkan di atas sangat dibutuhkan.

\section{DAFTAR PUSTAKA}

Candy, Philip C., "Independent Learning: Some Ideas from Literature", (http://www. brookes.ac.uk/ services/ocsd/2learntch/independent. html).

Keegan, Desmond, "Foundations of Distance Education", (London: Routledge, 1990).

Knowless, Malcolm S., "Self-Directed Learning: A Guide for Learners and Teachers", (Chicago: Association Press: Follet Publishing Company, 1975).

Kozma, Robert B.; Belle, Lawrence W.; dan Williams George W.; (1978),

"Instructional Techniques in Higher Education", (New Jersey:

Educational Technology Publications, 1978).

Miarso, Yusufhadi, "Konsep Dasar Pengembangan Sistem Belajar Mandiri”, Makalah disajikan pada Lokakarya Pusat Pengembangan

Penataran Guru Tertulis, Lembang, Bandung, 19 Nopember 1996. Moleong, Lexy J., “Metodologi Penelitian Kualitatif”, (Bandung: PT Remaja Rosdakarya, 2001).

Plomp, Tjeerd \& Donald P. Ely, "International Encyclopedia of 
Educational Technology", (Cam-bridge, UK: Elsevier Science Ltd., 1996).

Rogers, Everett, M., "Diffussion of Innovation", (Canada: The Free Press of Macmillan Publishing Co., 1983).

Rowntree, Derek, "Exploring Open and Distance Learning", (London: Kogan Page Limited, 1992).

Yin, Robert K.; (1984), "Case Study Research: Design and Methods", (Beverly Hills: Sage Publication, 1984). 